\title{
Article \\ Nutrient Uptake and Yield of Chinese Cabbage (Brassica rapa L. Chinensis) Increased with Application of Macadamia Husk Compost
}

\author{
Dembe Maselesele $^{1}\left(\mathbb{D}\right.$, John B. O. Ogola ${ }^{1, *(D)}$ and Romeo N. Murovhi ${ }^{2}$ \\ 1 Department of Plant and Soil Sciences, University of Venda, Private bag X5050, \\ Thohoyandou 0950, South Africa; dmaselesele@gmail.com \\ 2 Agricultural Research Council, Institute for Tropical and Sub-Tropical Crops, P.O. Box 247, \\ Levubu 0929, South Africa; romeo@arc.agric.za \\ * Correspondence: ochanda@univen.ac.za; Tel.: +27-15-9629005
}

Citation: Maselesele, D.; Ogola J.B.O.; Murovhi, R.N. Nutrient Uptake and Yield of Chinese Cabbage (Brassica rapa L. Chinensis) Increased with Application of Macadamia Husk Compost. Horticulturae 2022, 8, 196. https://doi.org/10.3390/ horticulturae 8030196

Academic Editor: Luigi De Bellis

Received: 8 February 2022

Accepted: 19 February 2022

Published: 23 February 2022

Publisher's Note: MDPI stays neutral with regard to jurisdictional claims in published maps and institutional affiliations.

Copyright: (C) 2022 by the authors. Licensee MDPI, Basel, Switzerland. This article is an open access article distributed under the terms and conditions of the Creative Commons Attribution (CC BY) license (https:// creativecommons.org/licenses/by/ $4.0 /)$
Abstract: There is a dearth of information on the effect of macadamia husk compost (MHC) on the productivity of short-season, shallow-rooted annual crops. We assessed the response of yield and nutrient uptake of Chinese cabbage (Brassica rapa L. Chinensis) to MHC application. The treatments (zero control, inorganic fertilizer (100:60:60 $\mathrm{kg} \mathrm{NPK} \mathrm{ha}^{-1}$ ), and 15 and $30 \mathrm{tha}^{-1} \mathrm{MHC}$ ) were arranged in a randomized complete block design and replicated three times. Number of leaves, leaf area index, leaf biomass, and leaf nutrient concentration ( $\mathrm{N}, \mathrm{P}, \mathrm{K}, \mathrm{Ca}, \mathrm{Mg}, \mathrm{Zn}, \mathrm{Cu}, \mathrm{Mn}$, and $\mathrm{B}$ ) were determined at 28,46 , and 74 days after transplanting (DAT), and root length and root biomass were determined at 74 DAT. Inorganic fertilizer and MHC increased root biomass and root length with greater increases recorded at the higher MHC rates. Number of leaves, leaf area index, leaf biomass, and nutrient concentration were greater with application of inorganic fertilizer (28 DAT) and $30 \mathrm{tha}^{-1}$ (74 DAT) suggesting that the effect of organic soil amendments is more pronounced over the long run compared with inorganic fertilizers. The concentration of macronutrients in the leaf increased with application of MHC and inorganic fertilizer. Clearly, MHC may be beneficial in improving the leaf yield and nutrient uptake of Chinese cabbage in a loamy sand soil, but the effect varies with time of harvesting.

Keywords: Brassica rapa; harvesting time; leaf nutrient concentration; macadamia husk compost; root biomass; root length

\section{Introduction}

Vegetables are important components in diets of rural families across the world as they provide vitamins and minerals. Chinese cabbage (Brassica rapa L. Chinensis) is one of the most popular vegetables in South Africa [1] and one of the most widely cultivated leafy vegetables in peri-urban smallholder farms in the northern part of South Africa [2]. Chinese cabbage originated in China, where it has been cultivated since the fifth century and is the most widely grown vegetable in China [1]. It has since spread to other parts of the world, including Africa, and Taiwan and Korea are other major producing countries [1]. Smallholder farmers in South Africa grow Chinese cabbage both for home consumption and as a source of cash income, mainly by selling through local markets and chain stores [3]. Chinese cabbage is rich in dietary fiber, vitamins, and minerals [4]. It has a short growing season, and it requires nitrogen $(\mathrm{N})$, phosphorus $(\mathrm{P})$, and potassium $(\mathrm{K})$ in relatively large quantities, to sustain rapid growth, as compared to other vegetables [5].

In South Africa, farmers continue to experience low yields of vegetables. This is attributed to water scarcity and deficiency of soil nutrients, which are major constraints that limit crop production amongst smallholder farmers in the semi-arid regions of South Africa [6]. Poor soil type, soil erosion, lack of fertilizer due to high cost, and lack of manure 
have been identified as factors that greatly contribute to low fertility $[7,8]$. The use of synthetic fertilizers is one option to obtain high yields. However, many smallholder farmers are disadvantaged because of high cost and poor accessibility [9]. Organic manures obtained from animals such as cattle, sheep, goats, and chicken have been used by smallholder farmers to enhance soil fertility, but their quantity is usually inadequate. Therefore, there is a need to focus on alternative, readily available sources of organic soil amendments, e.g., macadamia husks. The north-eastern region of South Africa, where the current study was conducted, is a major producer of macadamia nuts. Macadamia husks are the outer coating of the nut-in-shell and usually accumulate in stockpiles on farms because of de-husking process. Most of these husks end up in landfill while few farmers use the husks to make compost and feed animals. These husks are known to decompose quickly and release nutrients rapidly [10].

The use of compost as soil amendment has received much attention from farmers because of its benefit on soil productivity and crop growth and yield [11,12]. Compost addition improves root growth and thus indirectly improves nutrient availability to plants with consequent increases in leaf area development and crop yield [13-15]. A number of studies have documented the effect of compost, made from various feedstocks, on crop growth and yield [12,16,17], nutrient concentration [18-20], and leaf area [21-23]. These effects vary with feedstock type, application method, application rate, as well as soil type and environment.

There are some limited reports on the effect of macadamia husk compost on soil properties $[10,24,25]$ and yield, quality, and leaf nutrient concentration of macadamia [24]. However, there is a dearth of information in the literature on the effects of macadamia husk compost on the productivity of short-season, shallow-rooted annual crops. Therefore, we hypothesized that application of MHC would enhance the productivity of Chinese cabbage, a shallow-rooted annual species, which matures in 6-11 weeks. We have demonstrated the positive effects of MHC on soil physico-chemical properties [25]. In this paper we aimed to determine whether the positive effects of MHC on soil properties would lead to concomitant improvements in the productivity of Chinese cabbage. Specifically, we assessed the effect of MHC on root growth, leaf yield, root to leaf ratio, and leaf nutrient concentration of field-grown Chinese cabbage.

\section{Materials and Methods}

\subsection{Study Location}

A field experiment was conducted at the Agricultural Research Council Farm, Levubu (25 $27^{\prime} \mathrm{S}$ and $30^{\circ} 58^{\prime} \mathrm{E}$, and $877 \mathrm{~m}$ asl) in Limpopo Province, South Africa, in 2018 (season I) and 2019 (season II). The site is characterized by a sandy loam soil classified as Rhodic ferralsols [26], and receives an annual rainfall of approximately $752 \mathrm{~mm}$, with most of the rain occurring between November and February [27]. The daily temperatures in Levubu vary from about $24{ }^{\circ} \mathrm{C}$ to $40{ }^{\circ} \mathrm{C}$ in summer and between $20^{\circ} \mathrm{C}$ and $26^{\circ} \mathrm{C}$ in winter with an average minimum and maximum temperature of $10^{\circ} \mathrm{C}$ and $30^{\circ} \mathrm{C}$, respectively [27]. The details of soil physico-chemical properties of the site are described elsewhere [25].

Daily weather data for both seasons were obtained from an automatic weather station located approximately $100 \mathrm{~m}$ from the experimental site. Rainfall $(\mathrm{mm})$, relative humidity $(\%)$ maximum and minimum temperatures $\left({ }^{\circ} \mathrm{C}\right)$ were recorded each day during the experiments (Table 1). Season II was hotter and had higher evaporative demand compared to season I (Table 1). The site was under fallow conditions for 3 years prior to the establishment of the experiment. 
Table 1. Summary of weather during 2018 and 2019 cropping season in Levubu.

\begin{tabular}{cccccc}
\hline $\mathbf{2 0 1 8}$ & Max & Min & Mean & Rainfall & Relative \\
\hline Month & $\begin{array}{c}\text { Temp } \\
\left({ }^{\circ} \mathbf{C}\right)\end{array}$ & $\begin{array}{c}\text { Temp } \\
\left.\mathbf{(}{ }^{\circ} \mathbf{C}\right)\end{array}$ & $\begin{array}{c}\text { Temp } \\
\left({ }^{\circ} \mathbf{C}\right)\end{array}$ & $\mathbf{( m m )}$ & $\begin{array}{c}\text { Humidity } \\
\mathbf{( \% )}\end{array}$ \\
\hline April & 26 & 16 & 21 & 25.32 & 68 \\
May & 24 & 12 & 18 & 9.92 & 58 \\
June & 24 & 12 & 18 & 3.14 & 50 \\
July & 21 & 11 & 16 & 6.41 & 61 \\
August & 27 & 15 & 21 & 2.23 & 49 \\
\hline Mean/Total & 24.4 & 13.2 & 18.8 & 47.02 & 57.2 \\
\hline 2019 & & & & & \\
April & 29 & 18 & 23.5 & 34.1 & 69 \\
May & 28 & 16 & 22 & 6.3 & 56 \\
June & 25 & 13 & 19 & 15.4 & 58 \\
July & 27 & 14 & 20.5 & 1.9 & 40 \\
August & 28 & 16 & 22 & 7.4 & 48 \\
\hline Mean/Total & 27.4 & 15.4 & 21.4 & 65.1 & 54.2 \\
\hline
\end{tabular}

\subsection{Experimental Design and Agronomic Practices}

The experiment, consisting of a factorial combination of four fertilizer treatments (zero control (no fertilizer), inorganic fertilizer (IF), macadamia husk compost at $15 \mathrm{tha}^{-1}$ (MHC1), and macadamia husk compost at $30 \mathrm{t} \mathrm{ha}^{-1}$ (MHC2)) and three harvest times (28, 48, and 74 days after transplanting), was laid out in a randomized complete block design. The treatments were replicated three times giving a total of 12 plots with individual experimental plots measuring $13.5 \mathrm{~m}^{2}(2.7 \times 5 \mathrm{~m})$. The plots were $1 \mathrm{~m}$ apart from each other to avoid encroachment of macadamia husk compost and inorganic fertilizer. Inorganic fertilizer was applied 2 weeks after planting by ringing around individual plants at a rate of $100 \mathrm{~kg} \mathrm{~N} \mathrm{ha}^{-1}, 60 \mathrm{~kg} \mathrm{P} \mathrm{ha}^{-1}, 60 \mathrm{~kg} \mathrm{~K} \mathrm{ha}^{-1}$; these rates were based on previous studies [28]. In contrast, macadamia husk compost was incorporated into the soil a month before planting at a depth of $15 \mathrm{~cm}$. The physico-chemical properties of the MHC used are reported elsewhere but briefly it had a $\mathrm{pH}$ of 6.6 , high level of total $\mathrm{C}\left(312 \mathrm{~g} \mathrm{~kg}^{-1}\right)$, low N $\left(17.8 \mathrm{~g} \mathrm{~kg}^{-1}\right)$, moderate $\mathrm{C}: \mathrm{N}$ ratio (17.5), moderate levels of $\mathrm{P}\left(570 \mathrm{mg} \mathrm{kg}^{-1}\right), \mathrm{K}\left(27.9 \mathrm{~g} \mathrm{~kg}^{-1}\right)$, $\mathrm{Na}\left(166 \mathrm{mg} \mathrm{kg}^{-1}\right), \mathrm{Mg}\left(300 \mathrm{~g} \mathrm{~kg}^{-1}\right), \mathrm{Ca}\left(380 \mathrm{~g} \mathrm{~kg}^{-1}\right), \mathrm{Mn}\left(319 \mathrm{mg} \mathrm{kg}^{-1}\right), \mathrm{Al}\left(316 \mathrm{mg} \mathrm{kg}^{-1}\right)$, and very low $\mathrm{Zn}$ and $\mathrm{Cu}$ (28 and $22 \mathrm{mg} \mathrm{kg}^{-1}$, respectively) levels [25]. In addition, we showed that the application of MHC decreased bulk density and increased water holding capacity, soil $\mathrm{pH}$, organic carbon, total $\mathrm{N}, \mathrm{C}: \mathrm{N}$ ratio, available $\mathrm{P}$, and exchangeable cations, but the effects were more pronounced at MHC2 compared to MHC1 [25].

Chinese cabbage (cv. Florida broadleaf) seeds were obtained from VBK agriculture (Pty) Ltd. and were planted in trays filled with planting medium on the 12 March 2018 (season 1) and 8 April 2019 (season 2). Healthy seedlings of uniform sizes were selected and uprooted carefully, to avoid any damage to the root system, and were transplanted at a spacing of $40 \times 40 \mathrm{~cm}$ on the 6 April 2018 (season I) and 3 June 2019 (season II). Each experimental plot consisted of 6 plant rows, each $5 \mathrm{~m}$ long. All the plots were uniformly watered, 2-3 times a week, using micro irrigation jets. Manual weeding was used to keep the plots weed-free throughout the cropping season. Malasol Mercatothion (Organophosphate) was applied at a rate of $12.5 \mathrm{~mL}$ per $10 \mathrm{~L}$ of water once every two weeks to control insect pests.

\subsection{Number of Leaves, Leaf Area Index and Leaf Biomass}

Six plants from two inner rows were randomly selected at every harvest and used for determination of yield (number of leaves and leaf biomass) and leaf area index. Harvesting of leaves was performed manually using a sharp knife at 28,47 , and 74 days after transplanting (DAT). Number of leaves was determined by counting the number of leaves 
found in each plot, and the harvested leaves were oven-dried at $65{ }^{\circ} \mathrm{C}$ for $48 \mathrm{~h}$ to determine leaf biomass $\left(\mathrm{g} \mathrm{m}^{-2}\right)$. Leaf area was measured using LI-COR LI-300 area meter.

\subsection{Root Length, Root Biomass, and Root to Leaf Ratio}

At final harvest (74 DAT), sampled plants were carefully uprooted for determination of root length and root biomass. The roots were gently washed with tap water to remove adhering soils and other foreign particles. Root length was measured using a steel ruler and fresh root biomass was measured using a weighing balance. After determining root length and fresh root biomass, roots were dried in an oven for $48 \mathrm{~h}$ at $65^{\circ} \mathrm{C}$ for determination of root dry weight. Leaf and root dry weights were used to calculate the root to leaf ratio.

\subsection{Determination of Leaf Nutrient Concentration}

The samples that were used for leaf dry matter determination were ground in a Willey mill with $1.0 \mathrm{~mm}$ mesh. All the ground samples were stored in glass bottles for subsequent nutrient concentration ( $\mathrm{N}, \mathrm{P}, \mathrm{K}, \mathrm{Ca}, \mathrm{Mg}, \mathrm{Fe}, \mathrm{B}$, and $\mathrm{Mn}$ ) analysis. Leaves were analyzed for total $\mathrm{N}$ using micro Kjeldahl procedure outlined by Okalebo et al. [29]. Total phosphorus and boron were determined using a spectrophotometer at a wavelength of $660 \mathrm{~nm}$, and K, $\mathrm{Ca}, \mathrm{Mg}, \mathrm{Zn}$, and $\mathrm{Mn}$ were determined using the Atomic Absorption Spectrometer [30].

\subsection{Statistical Analysis}

Analysis of variance (ANOVA), using the general linear model procedure of Genstat $\left(18^{\text {th }}\right.$ edition), was used to assess the treatment effects. Where significant $(p<0.05)$, Fisher's least significant difference (LSD) test was used to separate the means. We conducted Pearson's correlation analysis to determine the relationship between root growth (biomass and length) and yield components.

\section{Results}

\subsection{Number of Leaves}

There was an interactive effect of harvesting time and treatment on the number of leaves in both seasons (Figure 1a,b). Only IF increased the number of leaves at first harvest, while both IF and MHC increased the number of leaves at the second and final harvests in 2018 (Figure 1a). Moreover, the highest number of leaves was recorded in plots amended with IF during the first harvest while on the last harvest, the highest number of leaves was recorded in plots amended with $30 \mathrm{t} \mathrm{ha}^{-1}$ of macadamia husk compost (Figure 1a). A similar trend was observed in the second season (Figure 1b). Averaged across the three harvests, application of inorganic fertilizer and MHC resulted in a higher number of leaves compared to control in both seasons (Figure 1a,b). The number of leaves harvested at 74 DAT was higher compared to the number of leaves harvested at both 28 (first harvest) and 46 (second harvest) DAT in season I (Figure 1a), but the main effect of harvesting time on the number of leaves was not significant in 2019 (Figure 1b).

\subsection{Leaf Area Index}

The interaction between fertilizer treatment and harvesting time affected the LAI in both seasons (Figure 2a,b). Although IF and MHC increased the LAI at all harvest dates in the first season, the highest LAI was recorded in plots amended with IF and MHC2 (28 and 46 DAT) and MHC2 (74 DAT), which was the highest across all the harvest dates (Figure 2a). In the second season in contrast, the highest LAI was recorded in plots amended with IF (first harvest) and MHC2 (second and final harvests) (Figure 2b). Moreover, the main effects of fertilizer treatment and harvest time on the LAI was significant in both years (Figure 2a,b). 


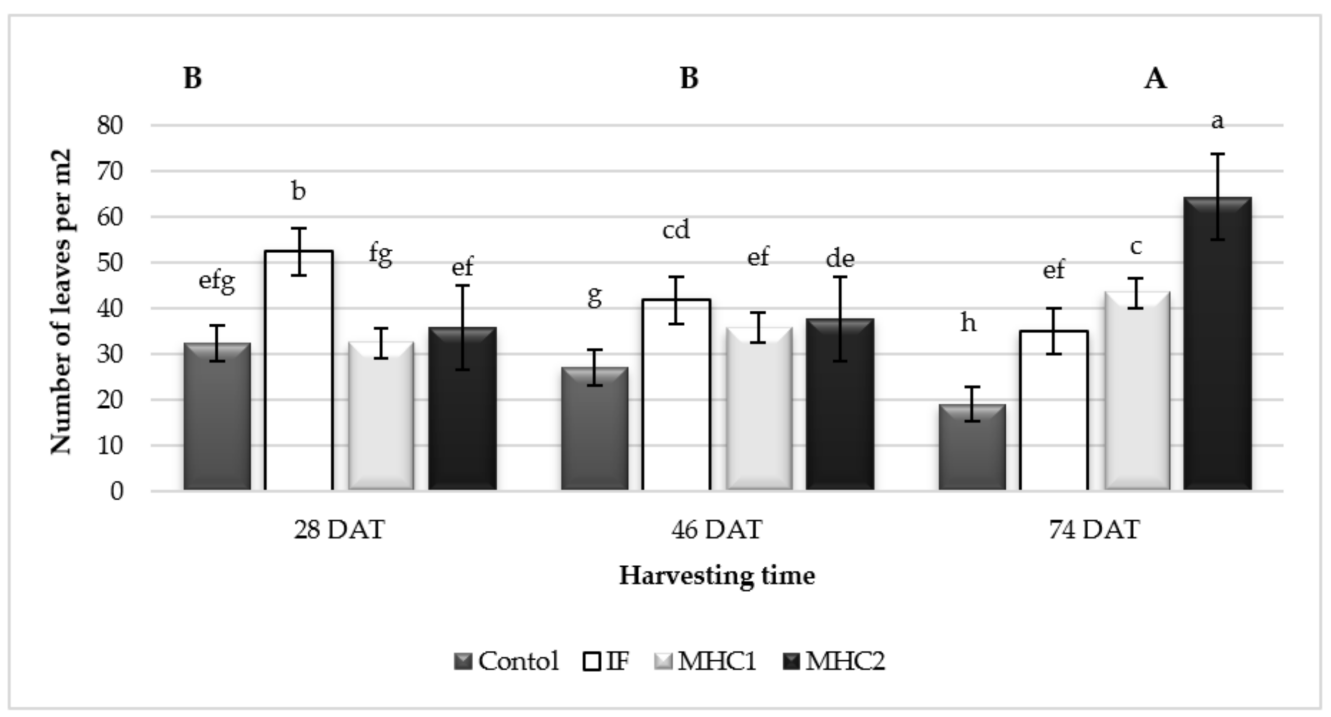

(a)

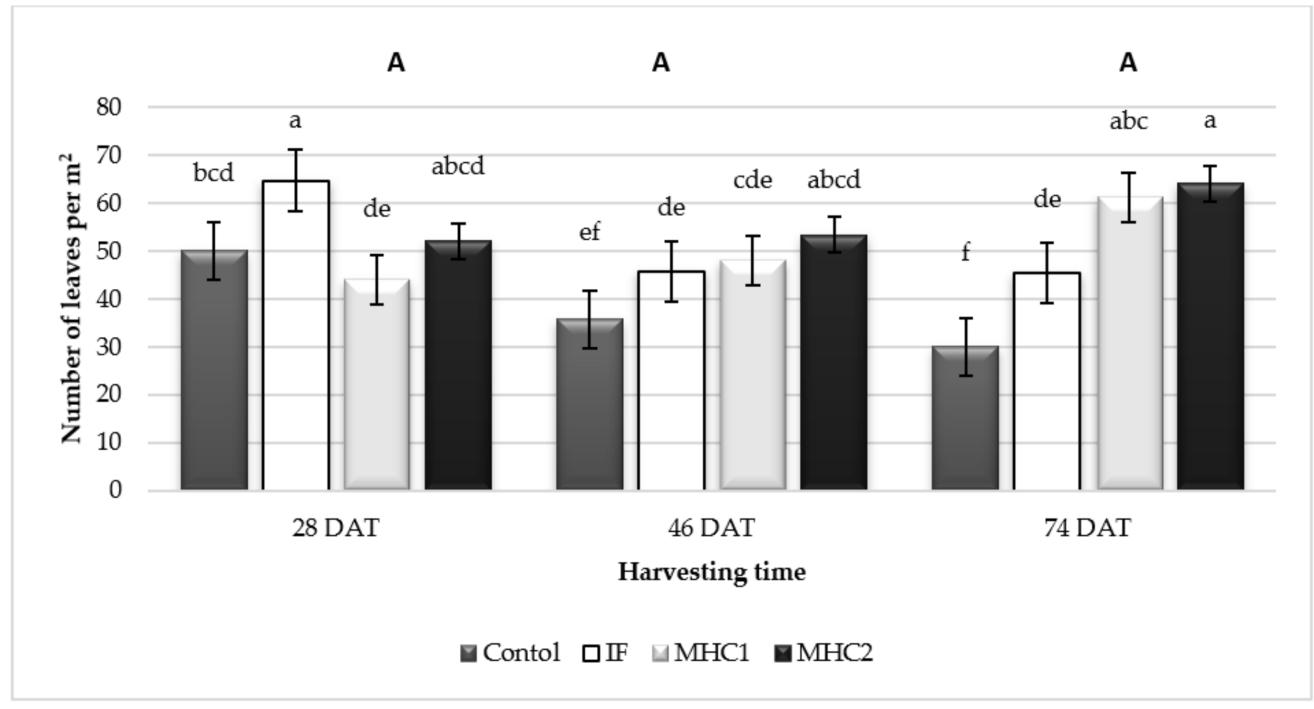

(b)

Figure 1. Effect of macadamia husk compost and inorganic fertilizer on number of leaves during three harvest period, 28 DAT = Harvest 1, 46 DAT = Harvest 2, Harvest $3=74$ DAT, in 2018 (a) and 2019 (b). Different small letters indicate significant differences between fertilizer levels and harvest time $(p<0.01 \& p<0.05$ in $2018 \& 2019$, respectively), and different capital letters indicate significant differences between harvest time $(p<0.01)$.

\subsection{Leaf Biomass}

Similar to the number of leaves and LAI, leaf biomass was affected by the interaction between fertilizer treatment and time of harvest in both seasons (Figure $3 a, b$ ). In the first season, the highest leaf biomass was recorded in plots that were amended with IF (first harvest), IF and MHC2 (second harvest) and MHC2 (final harvest), which was the highest across the three harvest dates (Figure 3a). A similar trend was recorded in the second season, except for the second harvest (Figure 3b). In addition, leaf biomass (averaged across fertilizer treatments and harvest time, respectively) was greater with application of IF and MHC compared to the control in both seasons (Figure 3a,b), and at the final harvest in season I (Figure 3a). 


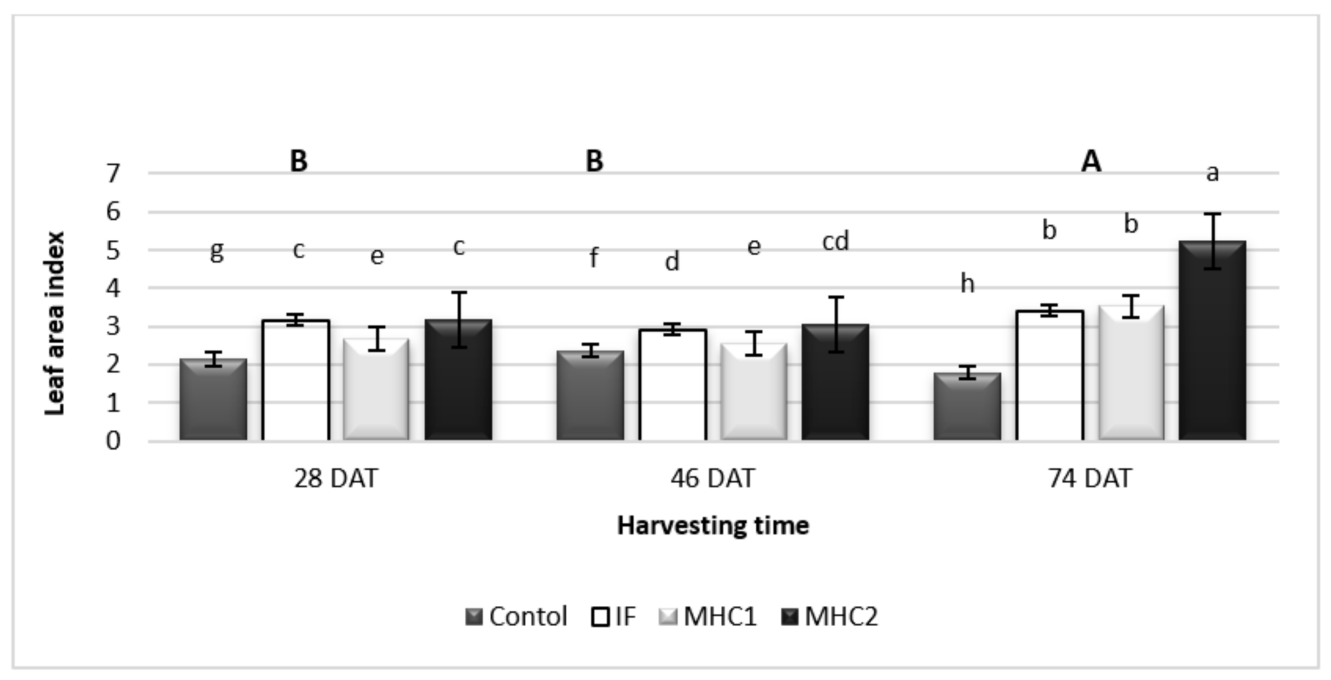

(a)

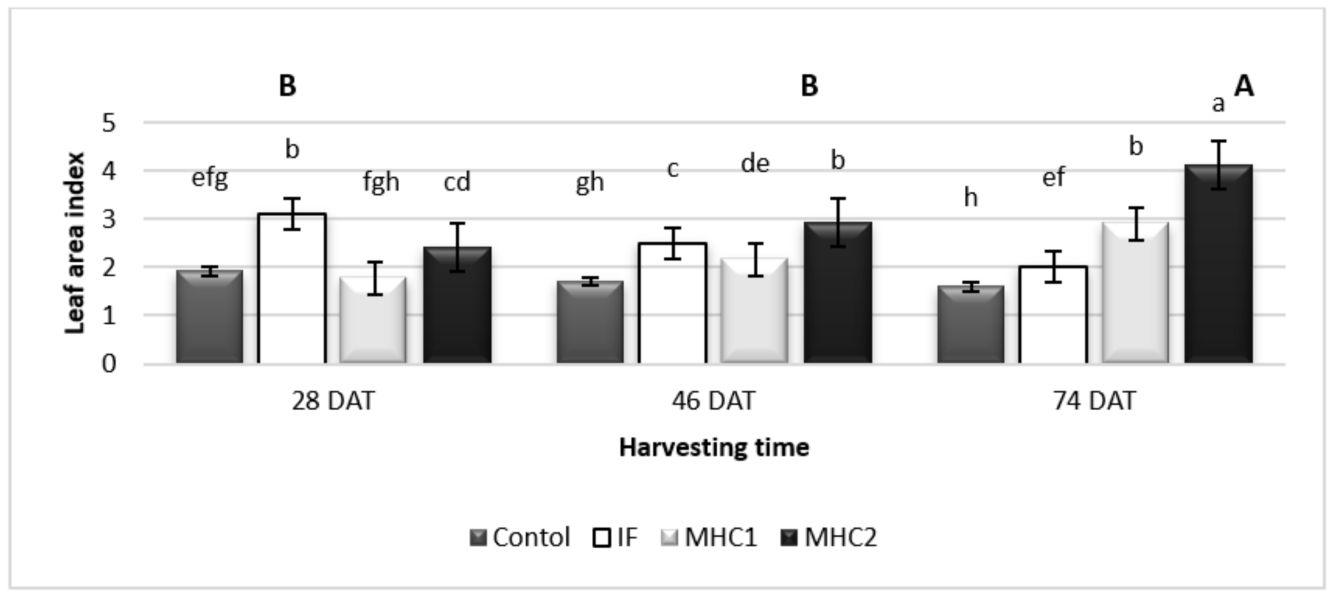

(b)

Figure 2. Effect of macadamia husk compost and inorganic on leaf area index during three harvest period, 28 DAT = Harvest 1, 46 DAT = Harvest 2, Harvest 3 = 74 DAT, in 2018 (a) and 2019 (b). Different small letters indicate significant differences between fertilizer levels and harvest time $(p<0.01)$, and different capital letters indicate significant differences between harvest time $(p<0.01$ in 2018 and $p<0.05$ in 2019.

\subsection{Root Biomass, Root Length, and Root to Leaf Ratio}

The effect of the application of macadamia husk compost on root biomass was significant in both seasons in contrast to inorganic fertilizer, which affected root biomass only in the second season (Table 2). The increase in root biomass was greater with MHC2 (3.5-fold in both seasons) compared with MHC1 (2.6- and 1.8-fold in 2018 and 2019, respectively) (Table 2). The root biomass recorded in plots amended with IF did not differ significantly with root biomass from MHC1 plots in both seasons (Table 2). 


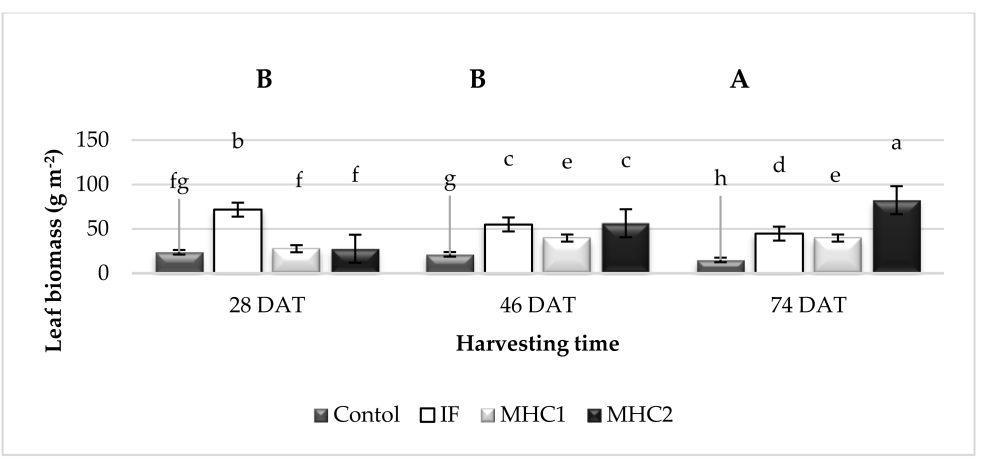

(a)

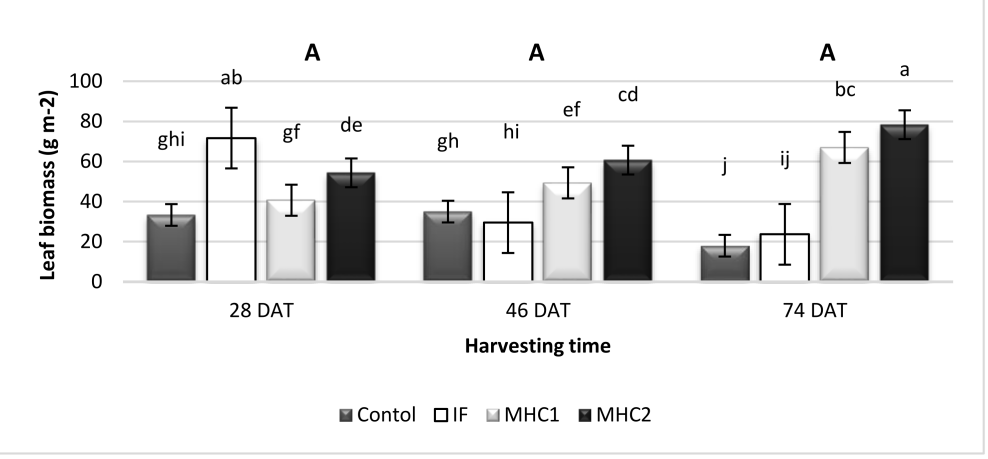

(b)

Figure 3. Effect of macadamia husk compost and inorganic fertilizer on leaf biomass (DW) during three harvest period, 28 DAT = Harvest 1, 46 DAT = Harvest 2, Harvest $3=74$ DAT, in 2018 (a) and 2019 (b). Different small letters indicate significant differences between fertilizer levels and harvest time $(p<0.01)$, and different capital letters indicate significant differences between harvest time $(p<0.01)$.

Table 2. Effect of macadamia husk compost and inorganic fertilizer on root biomass (DW), root length, and root to shoot ratio (DW) in 2018 and 2019.

\begin{tabular}{|c|c|c|c|}
\hline \multirow{2}{*}{ Treatments } & Root Biomass & Root Length & Root/Shoot Ratio \\
\hline & $\left(\mathrm{g} \mathrm{m}^{-2}\right)$ & $(\mathrm{cm})$ & \\
\hline \multicolumn{4}{|c|}{ Year I (2018) } \\
\hline Control & $0.30 \pm 0.10 c$ & $11.2 \pm 1.20 \mathrm{~b}$ & $0.01 \pm 0.01$ \\
\hline IF & $0.80 \pm 0.36 \mathrm{bc}$ & $14.8 \pm 1.02 \mathrm{a}$ & $0.20 \pm 0.01$ \\
\hline MHC1 & $1.08 \pm 0.37 \mathrm{~b}$ & $14.8 \pm 0.45 a$ & $0.02 \pm 0.01$ \\
\hline MHC2 & $1.36 \pm 0.15 a$ & $16.6 \pm 1.15 \mathrm{a}$ & $0.02 \pm 0.01$ \\
\hline $\mathrm{P}($ F-test $)$ & $p<0.05$ & $p<0.05$ & $p<0.05$ \\
\hline LSD (0.05) & 0.538 & 2.168 & 0.011 \\
\hline $\mathrm{CV}(\%)$ & 30.4 & 7.6 & 30.12 \\
\hline \multicolumn{4}{|c|}{ Year II (2019) } \\
\hline Control & $0.29 \pm 0.06 c$ & $11.5 \pm 1.14 \mathrm{c}$ & $0.01 \pm 0.00$ \\
\hline IF & $0.82 \pm 0.17 \mathrm{~b}$ & $14.9 \pm 0.79 \mathrm{ab}$ & $0.02 \pm 0.01$ \\
\hline MHC1 & $1.03 \pm 0.12 b$ & $14.0 \pm 0.50 \mathrm{~b}$ & $0.02 \pm 0.00$ \\
\hline MHC2 & $1.30 \pm 0.16 \mathrm{a}$ & $16.2 \pm 1.17 \mathrm{a}$ & $0.02 \pm 0.00$ \\
\hline $\mathrm{P}($ F-test $)$ & $p<0.05$ & $p<0.05$ & $p<0.05$ \\
\hline LSD (0.05) & 0.266 & 2.041 & 0.01 \\
\hline Year & ns & ns & ns \\
\hline CV (\%) & 15.4 & 7.23 & 28.57 \\
\hline
\end{tabular}

Values are means \pm standard deviation; $n=12$; within a column means bearing the same letter are not statistically different; Control = no fertilizer; IF =100:60:60 $\mathrm{kg} \mathrm{NPK} \mathrm{ha}^{-1} ; \mathrm{MHC1}=$ Macadamia husk compost at 15 $\mathrm{tha}{ }^{-1}$; MHC2 $=$ Macadamia husk compost at $30 \mathrm{tha}^{-1}$. 
Application of macadamia husk compost and inorganic fertilizer increased root length by $32 \%$ (IF and MHC1) to $48 \%$ (MHC2) in the first season, and by $30 \%$ (IF) to $41 \%$ (MHC2) in the second season (Table 2). Root to shoot ratio was not affected by the application of macadamia husk compost and inorganic fertilizer in 2018 and 2019 (Table 2).

\subsection{The Relationship between Root Growth and Leaves}

There was a positive relationship between root biomass and number of leaves $(p<0.05)$, leaf biomass $(p<0.05)$, and leaf area index $(p<0.01)$. Similarly, significant $(p<0.01)$ positive relationship between root length and number of leaves, leaf biomass, and leaf area index was observed (Table 3).

Table 3. Correlation coefficients between root biomass, root length, and yield components.

\begin{tabular}{cccc}
\hline Variables & Number of Leaves & Leaf Biomass (DW) & Leaf Area Index \\
\hline Root biomass (DW) & $0.59^{*}$ & $0.50^{*}$ & $0.60^{* *}$ \\
Root length & $0.61^{* *}$ & $0.65^{* *}$ & $0.61^{* *}$ \\
${ }^{*}=p<0.05,{ }^{* *}=p<0.01$. & &
\end{tabular}

\subsection{Leaf Nutrient Concentration}

\subsubsection{Leaf N Concentration}

Macadamia husk compost and inorganic fertilizer increased the concentration of leaf N nutrient by 139\% (IF), 145\% (MHC1), and 196\% (MHC2) in the first season and by 49\% (MHC1), 91\% (IF), and 134\% (MHC2) in the second season (Tables 4 and 5). Higher $\mathrm{N}$ leaf concentration was recorded at the last harvest compared to the first and second harvests in 2018 (Table 4), but harvesting time did not affect N concentration in 2019 (Table 5).

Table 4. Effect of macadamia husk compost and inorganic fertilizer on leaf nutrient concentration in 2018.

\begin{tabular}{|c|c|c|c|c|c|c|c|c|c|}
\hline Treatments & $\mathbf{N}$ & $\mathbf{P}$ & $\mathbf{K}$ & $\mathrm{Ca}$ & Mg & Zn & $\mathrm{Cu}$ & Mn & B \\
\hline \multicolumn{10}{|c|}{$\left(\mathrm{mg} \mathrm{kg}^{-1} \mathrm{DW}\right)$} \\
\hline \multicolumn{10}{|l|}{$\begin{array}{l}\text { Fertilizer } \\
\text { (F) }\end{array}$} \\
\hline Control & $81 \pm 22.2 c$ & $8.5 \pm 1.87 c$ & $95 \pm 15.6 c$ & $54 \pm 19.6 c$ & $11 \pm 3.6 \mathrm{a}$ & $38 \pm 3.0$ & $11 \pm 2.1$ & $52 \pm 20.7 a$ & $69 \pm 32.7$ \\
\hline IF & $194 \pm 46.2 b$ & $22 \pm 7.7 \mathrm{~b}$ & $241 \pm 83.2 b$ & $\begin{array}{l}118 \pm \\
36.2 b\end{array}$ & $23 \pm 7.3 b$ & $37 \pm 4.5$ & $11 \pm 1.9$ & $47 \pm 17.1 \mathrm{ab}$ & $62 \pm 28.5$ \\
\hline MHC1 & $199 \pm 102.1 b$ & $24 \pm 8.1 b$ & $237 \pm 113.1 b$ & $138 \pm 88.0 c$ & $19 \pm 5.6 b$ & $38 \pm 2.5$ & $11 \pm 2.6$ & $46 \pm 23.4 \mathrm{ab}$ & $61 \pm 29.1$ \\
\hline MHC2 & $240 \pm 125.7 a$ & $26 \pm 7.5 a$ & $283 \pm 146.2 a$ & $147 \pm 63.6 a$ & $32 \pm 16.4 c$ & $36 \pm 4.1$ & $10 \pm 3.2$ & $41 \pm 10.2 b$ & $60 \pm 40.8$ \\
\hline LSD (0.05) & 15.11 & 2.87 & 27.69 & 13.91 & 3.43 & 2.85 & 1.91 & 9.95 & 5.99 \\
\hline \multicolumn{10}{|l|}{$\begin{array}{l}\text { Harvesting } \\
\text { time }(\mathrm{HT})\end{array}$} \\
\hline $28 \mathrm{DAT}$ & $115 \pm 45.3 c$ & $19 \pm 8.2 c$ & $174 \pm 67.3 b$ & $74 \pm 31.3 b$ & $13 \pm 5.5 c$ & $36 \pm 3.5$ & $8.5 \pm 1.44 b$ & $29 \pm 10.0 c$ & $40 \pm 6.0 c$ \\
\hline $26 \mathrm{DAT}$ & $150 \pm 56.3 b$ & $17 \pm 7.1 b$ & $157 \pm 69.2 b$ & $90 \pm 32.1 b$ & $23 \pm 10.0 b$ & $36 \pm 2.8$ & $11 \pm 1.8 \mathrm{a}$ & $46 \pm 4.4 b$ & $59 \pm 21.0 b$ \\
\hline 74 DAT & $271 \pm 111.8 \mathrm{a}$ & $24 \pm 11.9 a$ & $313 \pm 148.0 \mathrm{a}$ & $178 \pm 72.4 \mathrm{a}$ & $29 \pm 14.5 a$ & $40 \pm 3.2$ & $11 \pm 2.9 \mathrm{a}$ & $65 \pm 15.6 a$ & $90 \pm 21.2 \mathrm{a}$ \\
\hline LSD 0.05 & 13.09 & 2.49 & 23.97 & 12.05 & 2.96 & 2.46 & 1.651 & 8.63 & 5.18 \\
\hline \multicolumn{10}{|l|}{$p$ (F-test $)$} \\
\hline $\mathrm{F}$ & $p<0.05$ & $p<0.05$ & $p<0.05$ & $p<0.05$ & $p<0.05$ & ns & ns & ns & ns \\
\hline HT & $p<0.05$ & $p<0.05$ & $p<0.05$ & $p<0.05$ & $p<0.05$ & ns & $p<0.01$ & $p<0.01$ & $p<0.01$ \\
\hline $\mathrm{F}^{*} \mathrm{HT}$ & $p<0.05$ & $p<0.05$ & $p<0.05$ & $p<0.05$ & $p<0.05$ & ns & ns & $\mathrm{ns}$ & ns \\
\hline CV (\%) & 8.7 & 14.4 & 13.1 & 12.5 & 16.2 & 7.8 & 18.4 & 21.9 & 28.5 \\
\hline
\end{tabular}


Table 5. Effect of macadamia husk compost and inorganic fertilizer on leaf nutrient concentration in 2019.

\begin{tabular}{|c|c|c|c|c|c|c|c|c|c|}
\hline Treatments & $\mathbf{N}$ & $\mathbf{P}$ & $\mathbf{K}$ & $\mathrm{Ca}$ & Mg & Zn & $\mathrm{Cu}$ & Mn & B \\
\hline \multicolumn{10}{|c|}{$\left(\mathrm{mg} \mathrm{kg}^{-1} \mathrm{DW}\right)$} \\
\hline \multicolumn{10}{|l|}{ Fertilizer } \\
\hline Control & $121 \pm 35.9 \mathrm{~d}$ & $13 \pm 4.7 c$ & $115 \pm 29.4 c$ & $59 \pm 23.2 d$ & $11 \pm 2.5 c$ & $38 \pm 3.5$ & $9.8 \pm 2.37$ & $51 \pm 5.4$ & $42 \pm 5.9$ \\
\hline NPK & $181 \pm 103.4 c$ & $17 \pm 9.9 c$ & $186 \pm 89.3 b$ & $93 \pm 41.2 c$ & $23 \pm 12.9 b$ & $39 \pm 3.4$ & $10 \pm 2.4$ & $61 \pm 14.5$ & $47 \pm 10.2$ \\
\hline MHC1 & $231 \pm 63.9 b$ & $24 \pm 6.7 \mathrm{~b}$ & $207 \pm 51.8 b$ & $127 \pm 35.5 b$ & $23 \pm 10.1 b$ & $38 \pm 2.6$ & $11 \pm 1.9$ & $46 \pm 6.2$ & $50 \pm 5.0$ \\
\hline MHC2 & $284 \pm 63.6 a$ & $33 \pm 14.3 a$ & $296 \pm 66.8 \mathrm{a}$ & $192 \pm 54.4 \mathrm{a}$ & $29 \pm 5.2 \mathrm{a}$ & $40 \pm 2.9$ & $11 \pm 1.8$ & $47 \pm 4.3$ & $51 \pm 8.5$ \\
\hline LSD (0.05) & 14.2 & 4.45 & 30.77 & 17.43 & 4.86 & 4.08 & 1.372 & 5.84 & 7.11 \\
\hline \multicolumn{10}{|l|}{$\begin{array}{l}\text { Harvesting } \\
\text { time }(\mathrm{HT})\end{array}$} \\
\hline 28 DAT & $208 \pm 71.2$ & $20 \pm 6.17$ & $204 \pm 72.2$ & $105 \pm 32.4 b$ & $23 \pm 11.4$ & $39 \pm 3.0$ & $10 \pm 2.3$ & $47 \pm 5.1 b$ & $50 \pm 9.1$ \\
\hline 46 DAT & $204 \pm 62.8$ & $22 \pm 8.8$ & $199 \pm 67.7$ & $128 \pm 57.3 b$ & $20 \pm 8.3$ & $38 \pm 3.4$ & $10 \pm 2.6$ & $49 \pm 7.8 \mathrm{ab}$ & $48 \pm 8.8$ \\
\hline 74 DAT & $203 \pm 129.4$ & $22 \pm 18.5$ & $199 \pm 129.0$ & $112 \pm 88.5 a$ & $20 \pm 12.9$ & $40 \pm 2.9$ & $11 \pm 1.2$ & $57 \pm 12.7 \mathrm{a}$ & $51 \pm 6.7$ \\
\hline LSD 0.05 & 25.11 & 3.85 & 26.64 & 12.05 & 4.21 & 3.53 & 1.19 & 5.85 & 8.43 \\
\hline \multicolumn{10}{|l|}{$P(F-t e s t)$} \\
\hline $\mathrm{F}$ & $p<0.05$ & $p<0.05$ & $p<0.05$ & $p<0.05$ & $p<0.05$ & ns & ns & ns & ns \\
\hline $\mathrm{HT}$ & ns & ns & ns & $p<0.05$ & ns & ns & ns & ns & ns \\
\hline $\mathrm{F}^{*} \mathrm{HT}$ & $p<0.05$ & $p<0.05$ & $p<0.05$ & $p<0.05$ & $p<0.05$ & ns & ns & ns & ns \\
\hline CV $(\%)$ & 14.2 & 20.5 & 15.4 & 12.5 & 19.6 & 5.6 & 13.1 & 11.3 & 14.7 \\
\hline
\end{tabular}

\subsubsection{Leaf P Concentration}

Macadamia husk compost and NPK fertilizer increased P nutrient concentration in the leaves in 2018, but the increase was much greater with MHC2 (210\%) compared with MHC1 (179\%) and IF (164\%) (Table 4). Similarly, MHC increased P nutrient concentration in 2019, but the effect of IF was non-significant (Table 5). The concentration of P in the leaves was higher at 74 DAT compared to 28 (first harvest) and 46 (second harvest) DAT in the first season (Table 4). In contrast, the effect of harvesting time on leaf P concentration was not significant in season II (Table 5).

\subsubsection{Leaf K Concentration}

The concentration of $\mathrm{K}$ in the leaves increased with the application of macadamia husk compost and inorganic fertilizer, but the increase was much greater with MHC2 (3-fold and 2.6-fold, respectively in 2018 and 2019) compared with MHC1 (151\% in season I and 1.8-fold in the second season) and IF (154\% in 2018 and 1.6-fold in 2019) (Tables 4 and 5). Time of harvest had a significant effect on leaf $\mathrm{K}$ concentration in season I, with the final harvest recording the highest leaf $\mathrm{K}$ concentration compared to the first and second harvests, which were statistically the same (Table 4). Harvesting time had no effect on leaf $\mathrm{K}$ concentration in season II (Table 5).

\subsubsection{The Concentration of $\mathrm{Ca}$ and $\mathrm{Mg}$ in the Leaf}

The effect of macadamia husk compost and inorganic fertilizer on leaf Ca concentration was significant in 2018 but the increase was much higher in MHC1 $(156 \%)$ and MHC2 (173\%) compared with IF (120\%) (Table 4). A similar trend was observed in 2019 (Table 5). Harvesting time affected Ca leaf concentration in both seasons, with higher Ca leaf concentrations recorded at 74 DAT compared to 46 and 28 DAT, which were not significantly different from each other (Tables 4 and 5).

MHC and IF increased Mg leaf concentration in both seasons, with greater increase at MHC2 (Tables 4 and 5). Harvesting time had a significant effect on $\mathrm{Mg}$ leaf concentration in 2018, with higher Mg leaf concentration recorded during the third harvest (Table 4). In contrast, harvesting time did not affect the concentration of Mg in the leaf in 2019 (Table 5). 


\subsubsection{The Concentration of $\mathrm{Zn}, \mathrm{Cu}, \mathrm{Mn}$, and $\mathrm{B}$ in the Leaf}

Application of macadamia husk compost and inorganic fertilizer and the interaction between fertilizer treatment and harvest time did not affect the leaf concentrations of $\mathrm{B}$, $\mathrm{Cu}, \mathrm{Mn}$, and $\mathrm{Zn}$ in both seasons (Tables 4 and 5). In contrast, harvesting time affected the leaf concentrations of B, Cu (2018), and Mn (2018 and 2019). The concentration of $\mathrm{Cu}$ in the leaf was higher during the last two harvests (statistically the same) compared to the first harvest (Table 4). However, the concentration of B in the leaf was in the order of 74 DAT $>46$ DAT $>28$ DAT (Table 4). Leaf Mn concentration followed a similar trend to B in 2018 (Table 4), but in 2019, only the last harvest had higher leaf Mn concentration compared to the first harvest (Table 5).

\section{Discussion}

The physical properties of the soil, which are indicators of soil quality, have a huge influence on root growth and development [31]. Plant roots grow well in soil that has good infiltration, drainage, water holding capacity, aggregate stability, porosity, and bulk density. Therefore, any management practice that improves soil physical properties is likely to enhance root growth and development. Moreover, there is a functional relationship between roots and shoots in most plant species and hence an increase in root growth is likely to lead to enhanced shoot biomass [32]. Therefore, we aimed at assessing whether the previously observed positive effects of macadamia husk compost on soil physical properties [25] would result in enhanced root growth and development and, hence, improved leaf yield of Chinese cabbage.

In the current study, application of macadamia husk increased root biomass and root length of Chinese cabbage probably due to an increase in the soil nutrient content as well as an improvement in soil physical properties, which created favorable conditions for root growth and development [33]. Similarly, Liu et al. [34] reported that application of composted pineapple increased root length of pineapples, which they attributed to the improvement of organic matter as well as available N, P, and K.

Inorganic fertilizer also increased root biomass and root length in the current study, perhaps due to supply of readily available nutrients [35]. Similarly, greater root length of radish and Amaranthus in plots that were amended with the recommended dose of inorganic fertilizer compared to control plots was attributed to proper supply of nutrients [33]. Earlier, Ogola et al. [36] attributed an increase in soil water extraction at 0.6-1.0 m soil depth in plots supplied with $100 \mathrm{~kg} \mathrm{~N} \mathrm{ha}^{-1}$ to more roots in these layers. Clearly, any management practice (s) that improve soil physical properties and/or availability of plant nutrients in the soil would lead to enhanced root growth and development. However, our study is the first one to report the effects of MHC on crop root length and biomass.

Total yield was determined in terms of number of leaves and leaf biomass. In addition, we assessed the response of leaf area index to IF and MHC application. The increase in leaf yield and leaf area index with application of MHC and inorganic fertilizer was likely due to a similar increase in root biomass and root length with IF and MHC, as suggested by the positive correlation between yield components and root biomass/length (Table 3). However, a greater number of leaves, leaf biomass, and LAI was recorded with IF compared to MHC during the first harvest in contrast to the final harvest where MHC2 recorded higher leaf yield and LAI (Figures 1,2 and 3a,b) probably due to readily available and mineralized nutrients from inorganic fertilizers $[23,33,37]$. The interactive effect between MHC and time of harvest on leaf yield we observed suggests that where MHC is used, the Swiss chard leaves should be harvested later in the season for maximum yield.

Inorganic fertilizers may outperform organic fertilizers in terms of improving growth and yield of crop plants if supplied judiciously but the effect of inorganic fertilizers is not sustainable [38], especially in soils characterized by low soil organic carbon (SOC) such as the site of the current study. The lower yield in IF compared to MHC-amended plots in the final harvest was probably due to low sustainability of nutrients supply from IF for long periods $[38,39]$. In contrast, an increase in yield components with time of harvest in plots 
supplied with compost was likely due to slow release of nutrients from compost and other organic sources $[39,40]$.

The increase in yield with MHC application observed in the current study could also be attributed, partly, to similar improvement in physico-chemical properties of soil in MHC-amended plots [25]. Unlike inorganic fertilizers, compost improves water holding capacity, bulk density, and helps to hold more nutrients, which therefore enhances crop production [41]. The higher yield of lettuce in compost compared to inorganic fertilizer treatments was similarly attributed to the improvement in soil physical, chemical, and biological properties [42].

In our findings, the application of $\mathrm{MHC}$ compost increased the concentration of $\mathrm{N}$, $\mathrm{P}$, and $\mathrm{K}$ nutrients in the leaves. The effect of $\mathrm{MHC}$ on leaf $\mathrm{N}, \mathrm{P}$, and $\mathrm{K}$ was expected due to the ability of organic manures to retain and supply nutrients to plants [43]. Moreover, this could be due to high content of $\mathrm{N}, \mathrm{P}$, and $\mathrm{K}$ in $\mathrm{MHC}$, which were released upon its decomposition [12,19]. The increase in $\mathrm{Ca}$ and $\mathrm{Mg}$ was also attributed to high amount of these nutrients in MHC [25], which is comparable to earlier observations [44]. In contrast to earlier reports [45], application of $\mathrm{MHC}$ did not affect the concentration of micronutrients in the leaf in the current study. However, the leaf micronutrient concentration we recorded are comparable to previous findings [5]. The increase in the leaf concentrations of N, P, K, $\mathrm{Ca}, \mathrm{Cu}, \mathrm{Mn}$, and $\mathrm{B}$ with harvesting that we observed was perhaps due to a longer period of uptake and accumulation of nutrients by the crop [45]. Similar to leaf yield, leaf nutrient concentration, except for the micronutrients, was generally greater with IF compared to MHC during the first harvest in contrast to the final harvest where MHC2 recorded higher leaf nutrient concentration (data not provided), probably due to readily available and mineralized nutrients from inorganic fertilizers [23,33,37].

\section{Conclusions}

The study showed that application of macadamia husk compost at the rate of 15 and $30 \mathrm{t} \mathrm{ha}^{-1}$ and NPK fertilizer improved root biomass and root length, and increased the number of leaves, leaf biomass, leaf area index, and the concentration of macronutrients in the leaves of Chinese cabbage with a greater effect observed in plots that were amended with $30 \mathrm{t} \mathrm{ha}^{-1} \mathrm{MHC}$. Moreover, the effect of MHC on leaf yield and leaf nutrient concentration was more pronounced at the final compared to the first two harvests, which suggests the importance of harvesting time in maximizing yield where MHC is used as a soil amendment strategy. Clearly, MHC has the potential of improving productivity and nutritional quality of shallow-rooted, short season annual crops such as Chinese cabbage, grown in sandy loam soils that are characterized by low SOC. However, we propose further studies, incorporating several soil types, leafy vegetables, and seasons, before definite conclusions (and hence recommendations) can be drawn.

Author Contributions: Conceptualization, J.B.O.O. and R.N.M.; methodology, D.M., J.B.O.O. and R.N.M.; formal analysis, D.M. and R.N.M.; investigation, D.M. and R.N.M.; resources, D.M., J.B.O.O. and R.N.M.; writing—original draft preparation, D.M.; writing—review and editing, J.B.O.O. and R.N.M.; supervision, J.B.O.O. and R.N.M.; project administration, D.M. and R.N.M.; funding acquisition, R.N.M. All authors have read and agreed to the published version of the manuscript.

Funding: This research was funded by the Agricultural Research Council (ARC), grant number P03000113 and the APC was funded by the University of Venda.

Institutional Review Board Statement: Not applicable.

Informed Consent Statement: Not applicable.

Acknowledgments: We thank Messrs Eric Mathebula and Jerry Sekhwama, who have gracefully consented to the acknowledgment, for technical support.

Conflicts of Interest: The authors declare no conflict of interest. The funders had no role in the design of the study; in the collection, analyses, or interpretation of data; in the writing of the manuscript, or in the decision to publish the results. 


\section{References}

1. Van Averbeke, W.; Netshithuthuni, C. Effect of irrigation scheduling on leaf yield of non-heading Chinese cabbage (Brassica rapa L. subsp. chinensis). S. Afr. J. Plant Soil. 2010, 27, 322-327. [CrossRef]

2. Mukwirimbaa, G.M.; Kritzinge, Q.; Aveling, T. A survey of brassica vegetable smallholder farmers in the Gauteng and Limpopo provinces of South Africa. J. Agric. Rural Dev. Trop. Subtrop. 2016, 117, 35-44.

3. Department of Agriculture, Forestry and Fisheries (DAFF). Chinese Cabbage (Brassica rapa L. Chinensis). 2013. Available online: https://www.nda.agric.za/docs/Brochures/chinese.pdf (accessed on 11 August 2018).

4. Peyvast, G.; Abbassi, M. Effect of commercial compost on yield and nitrate content of Chinese cabbage. Hortic. Environ. Biol. 2006, 47, 123-125.

5. Magnusson, M. Mineral fertilizers and green mulch in Chinese cabbage (Brassica pekinsensis (Lour.) Rupr): Effect on nutrient uptake, yield and internal tipburn. Acta Agric. Scand. Sect. B Plant Soil Sci. 2002, 52, 32-35.

6. Kundhlande, G.; Groenewald, D.C.; Baiphethi, M.N.; Viljoen, M.N.; Botha, J.J.; van Rensburg, L.D.; Anderson, J.J. Socio-economic study water conservation techniques in semi-arid areas. In Water Research Commission Report; WRC Report No. 1267/1/04; Water Research Commission: Pretoria, South Africa, 2004.

7. Ramaru, J.; Mamabolo, Z.; Lekgoro, J. Improving soil fertility management in South Africa: Learning through participatory extension approaches. In Managing Africa's Soils No.19; Russell Press: Nottingham, UK, 2000.

8. Jaja, E.T.; Barber, L.I. Organic and inorganic fertilizers in food production system in Nigeria. J. Biol. Agric. Hortic. 2017, 7 , 2224-3208.

9. Lusiba, S.; Odhiambo, J.; Ogola, J. Effect of biochar and phosphorus fertilizer application on soil fertility: Soil physical and chemical properties. Arch. Agron. Soil Sci. 2017, 63, 477-490. [CrossRef]

10. Cox, J.; Van-Zwieten, L.; Ayres, M.; Morris, S. Macadamia Husk Compost Improves Soil Health in Sub-tropical Horticulture. In Proceedings of the 3rd Australian and New Zealand Soils Conference, 'SuperSoil 2004', Sydney, Australia, 5-9 December 2004.

11. Tweib, S.A.; Rahman, R.A.; Kalil, M.S. A Literature Review on the Composting. Int. Conf. Environ. Ind. Innov. 2011, 12, 26-32.

12. Nguyen, T.T.; Fuentes, S.; Marschner, P. Effect of incorporated or mulched compost on leaf nutrient concentrations and performance of Vitis vinifera cv. J. Soil Sci. Plant Nutr. 2013, 13, 485-497. [CrossRef]

13. Walker, D.J.; Bernal, M.P. The effects of olive mill waste compost and poultry manure on the availability and plant uptake of nutrients in highly saline soil. Bioresour. Technol. 2008, 99, 396-403. [CrossRef]

14. Oworu, O.O.; Dada, O.A.; Majekodunmi, O.E. Influence of compost on growth, nutrient uptake and dry matter partitioning of grain Amaranths (Amaranthus hypochondriacus L.). Libyan Agric. Res. Canter J. Int. 2010, 1, 375-383.

15. Adamtey, N.; Cofie, O.; Ofosu-Budu, K.G.; Ofusu-Anim, J.; Laryea, K.B.; Forster, D. Effect of N-enriched co-compost on transpiration efficiency and water-use efficiency of maize (Zea mays L.) under controlled irrigation. Agric. Water Manag. 2010, 97, 995-1005. [CrossRef]

16. Polat, E.; Onus, A.N.; Demir, H. The effects of spent mushroom compost on quality and productivity of cucumber (Cucumis sativas L.) grown in greenhouses. Afr. J. Biotech. 2009, 8, 176-180.

17. Togun, A.O.; Akanbi, W.B.; Dris, R. Influence of compost and nitrogen fertilizer on growth, nutrient uptake and fruit yield of tomato (Lycopersicon esculentum). Field Crops Res. 2003, 2003 26, 98-105.

18. Polat, E.; Onus, A.N.; Demir, H. The effects of spent mushroom compost on yield and quality in Lettuce growing. J. Fac. Agric. Akdeniz Univ. 2004, 17, 149-154.

19. Anwar, Z.; Irshad, M.; Mahmood, Q.; Hafeex, F.; Bilal, M. Nutrient uptake and growth of spinach as affected by cow manure co-composted with poplar leaf litter. Int. J. Recycl. Org. Waste Agric. 2017, 6, 79-88. [CrossRef]

20. Adekayode, F.O.; Ogunkoya, M.O. Comparative effects of organic compost and NPK fertilizer on soil fertility, yield and quality of amaranths in southwest Nigeria. Int. J. Biol. Chem. Sci. 2011, 5, 490-499. [CrossRef]

21. El-Quesni, F.E.M.; Hashish, K.I.; Kandil, M.M.; Mazher, A.A.M. Impact of some biofertilizers and compost on growth and chemical composition of Jatropha curcas L. World Appl. Sci. J. 2013, 21, 927-932.

22. Gonzales, L.M.R.; Caralde, R.A.; Aban, M.L. Response of pechay (Brassica napus L.) to different level of compost fertilizer. Int. J. Sci. Res. Publ. 2015, 5, 2250-3153.

23. Rady, M.M.; Semida, W.M.; Hemida, K.A.; Abdelhamid, M.T. The effect of compost on growth and yield of Phaseolus vulgaris plants grown under saline. Int. J. Recycl. Org. Waste Agric. 2016, 5, 311-321. [CrossRef]

24. Bittenbender, H.C.; Hue, N.V.; Fleming, K.; Brown, H. Sustainability of organic fertilization of macadamia with macadamia husk-manure compost. Commun. Soil Sci. Plant Anal. 1988, 29, 409-419. [CrossRef]

25. Maselesele, D.; Ogola, J.B.O.; Murovhi, R.N. Macadamia husk compost improved physical and chemical properties of sandy soil. Sustainability 2021, 13, 6997. [CrossRef]

26. Fey, M.V. Soils of South Africa; Cambridge University Press: Cape Town, South Africa, 2010

27. Nkuna, T.R.; Odiyo, J.O. Relationship between temperature and rainfall variability in the Levubu sub-catchment, South Africa. Int. J. Environ. Sci. 2016, 1, 65-75.

28. Tripathi, K.M.; Dhakal, D.D.; Sab, S.C.; Baral, D.R.; Sharma, M.D. Evaluation of vermicompost and chemical fertilizers on performance of Pak choi (Brassic rapa Cv. Hong Tae) and soil biological process. J. Instit. Agric. Anim. Sci. 2015, 33, 243-250.

29. Okalebo, J.R.; Gathua, K.W.; Woomer, P.L. Fraction of organic matter by particle size. In Laboratory Method of Soil and Plant Analysis: A Working Manual; TSBF-KARI UNESCO: Nairobi, Kenya, 1993; pp. 66-68. 
30. Motsara, M.R.; Roy, R.N. Guide to laboratory establishment for plant nutrients analysis. In FAO Fertilizer and Plant Nutrition Bulletin; Food and Agriculture Organization: Rome, Italy, 2008; p. 219.

31. Malik, S.S.; Chauhan, R.C.; Laura, J.S.; Kapoor, T.; Abhilashi, R.; Sharma, N. Influence of organic and synthetic fertilizers on soil physical properties. Int. J. Curr. Microbiol. Appl. Sci. 2014, 3, 802-810.

32. Chimphango, S.B.M.; Ogola, J.B.O.; Maseko, S.; MacAlister, D.; Makonya, G.M. Balanced allocation of resources for acquisition of water and nutrients in field legumes. S. Afr. J. Bot. 2018, 115, 281-282. [CrossRef]

33. Islam, M.M.; Karim, A.J.M.S.; Jahiruddin, M.; Majid, N.K.; Miah, M.G.; Ahmed, M.M.; Hakim, M.A. Effect of organic manure and chemical fertilizers on crops in radish-stem amaranth-Indian spinach cropping pattern in homestead area. Aust. J. Crop Sci. 2011, 5, 1370-1378.

34. Liu, C.H.; Liu, Y.; Fan, C.; Kuang, S.Z. The effect of composted pineapple residue return on soil properties and the growth and yield of pineapple. J. Soil Sci. Plant Nutr. 2013, 13, 433-444. [CrossRef]

35. Kapourchal, A.; Pazira, E.; Homaee, M. Assessing radish (Raphanus sativus L.) potential for phytoremediation of lead polluted soils resulting from air pollution. Plant Soil Environ. 2009, 5, 202-206. [CrossRef]

36. Ogola, J.B.O.; Wheeler, T.R.; Harris, P.M. Water use of maize crops in response to nitrogen and irrigation. Field Crops Res. 2002, 78, 105-117. [CrossRef]

37. Kiran, M.; Jilani, M.S.; Waseem, K.; Sohail, M. Effect of organic manures and inorganic fertilizers on growth and yield of radish (Raphanus sativus L.). Pak. J. Agric. Res. 2016, 29, 363-372.

38. Adeniyan, O.A.; Ojo, A.O.; Akinbode, O.A.; Adediran, J.A. Comparative study of different organic manures and NPK fertilizer for improvement of soil chemical properties and dry matter yield of maize in two different soils. J. Soil Sci. Environ. Manag. 2011, 2, 9-13.

39. Masarirambi, M.T.; Hlawe, M.M.; Oseni, O.T.; Thokhozile, E.S. Effects of organic fertilizers on growth, yield, quality and sensory evaluation of red lettuce (Lactuca sativa L.) Veneza Roxa. Agric. Biol. J. N. Am. 2010, 1, 1319-1324. [CrossRef]

40. Mbatha, A.N.; Engelbretcht, G.M.; Ceronio, C.M. Response of carrot (Daucus carota L.) yield and quality to organic fertilizer. $S$. Afr. J. Plant Soil. 2014, 31, 1-6. [CrossRef]

41. Golabi, M.H.; Denney, M.J.; Iyekar, C. Use of composted organic wastes as alternative to synthetic fertilizers for enhancing crop productivity and agricultural sustainability on the tropical Island of Guam. In Proceedings of the 13th International Soil Conservation Organization Conference, Brisbane, Australia, 1-6 July 2004; p. 234.

42. Hossain, M.B.; Ryu, K.S. Effects of organic and inorganic fertilizers on lettuce (Lactuca sativa L.) and soil properties. J. Agric. Sci. 2017, 15, 93-102.

43. Anguria, P.; Chemiming'wa, G.N.; Onwonga, R.N.; Ugen, M.A. Effect of organic manures on nutrient uptake and seed quality of Sesame. J. Agric. Sci. 2017, 9, 1916-9752. [CrossRef]

44. Hernandez, A.; Castillo, H.; Ojeda, D.; Arras, A.; Lopez, J.; Sanchez, E. The effect of vermicompost and compost on lettuce production. Chil. J. Agric. Res. 2016, 70, 583-589. [CrossRef]

45. Viera, J.L.V.; Nardi, K.T.; Silva, G.R.A.; Moreira, L.A.; Zavaschi, E.; Moura, T.A.; Otto, R. Nutrient uptake by high-yielding cotton crop in Brazil. Rev. Bras. Cienc. Solo. 2018, 42, e0170033. [CrossRef] 